\title{
Laboratory Assays on the Effects of Aerated Compost Tea and Fertilization on Biochemical Properties and Denitrification in A Silt Loam and Bt Clay Loam Soils
}

\author{
Bryant C. Scharenbroch, William Treasurer, Michelle Catania, and Vincent Brand
}

\begin{abstract}
Aerated compost tea (ACT) is gaining interest as a nutrient amendment for urban trees. This study examined the effects of ACT, synthetic fertilizer, and deionized water on 15 biochemical properties with two soil types. Significant effects for $\mathrm{pH}, \mathrm{Mg}^{2+}, \mathrm{Na}^{+}, \mathrm{C}, \mathrm{N}$, and $\mathrm{C} / \mathrm{N}$ ratio were not observed among treatments. No differences between dilute $\mathrm{ACT}\left(\mathrm{ACT}_{\mathrm{d}}\right)$ at $22.4 \mathrm{~kL} \mathrm{ha}^{-1}$ and water were detected. Soil $\mathrm{K}^{+}$was greater with $\mathrm{ACT}_{\mathrm{concentrate}}\left(\mathrm{ACT}_{\mathrm{c}}\right)$ at $224 \mathrm{~kL} \mathrm{ha}^{-1}$ compared to 30-10-7 fertilizer at $195 \mathrm{~kg} \mathrm{~N}^{-1}{ }^{-1}$ with A horizon soils. Soil $\mathrm{K}^{+}, \mathrm{NH}_{4}^{+}$, and microbial respiration were greater with ACT compared to water in A soils. Soil $\mathrm{P}$ (A soils only), $\mathrm{NO}_{3}^{-}$(Bt soils only), dissolved organic N, microbial biomass $\mathrm{N}$, and $\mathrm{N}$ mineralization were greater with fertilizer compared to ACT. Increases in denitrification were seen with ACT compared to fertilizer and water in the first 24 hours $\left(+4\right.$ to $\left.+12 \mathrm{mg} \mathrm{N}_{2} \mathrm{O} \mathrm{kg}{ }^{-1}\right)$, but greater increases were observed with fertilizer at hours 48 and 96 ( +65 to $\left.+127 \mathrm{mg} \mathrm{N}_{2} \mathrm{O} \mathrm{kg}^{-1}\right)$. Greatest improvements in soil fertility were observed with fertilization. Minor improvements in soil fertility were observed with ACT, and denitrification losses were lower with ACT compared to the fertilizer.

Key Words. Compost Extract; Microbial Activity; Microbial Biomass; Nitrous Oxide; Nutrient Availability; Organic Fertilizer; Synthetic Fertilizer; Urban Trees.
\end{abstract}

Appropriate nutrient management of urban trees is important for tree and environmental health. Traditionally, supplemental nutrients to urban trees have been supplied primarily by inorganic fertilizers. When misapplied to urban landscapes, fertilizers represent threats to the environment. Phosphorus $(\mathrm{P})$ in fertilizer applied to urban landscapes has been identified as a significant contributor to $\mathrm{P}$ loads to lakes, potentially leading to algae blooms, reduced oxygen, and fish kills (Corsi et al. 1997; Soldat and Petrovic 2008). Nitrogen (N) applied in excess of plant demands contributes to the acidification of surface waters, eutrophication of coastal water, and groundwater contamination (Vitousek et al. 1997; Mitsch et al. 2001; Driscoll et al. 2003).

Traditionally it has been thought that fertilizers increase primary productivity, and thus increase soil carbon (C) through greater plant residue returned to the soil (Halvorson et al. 1999). However, recent findings have shown long-term fertilization to decrease soil $\mathrm{C}$ storage via $\mathrm{N}$ stimulation of soil microbes and associated increase in $\mathrm{CO}_{2}$ efflux (Khan et al. 2007; Mulvaney et al. 2009). Greenhouse gases are produced during fertilizer synthesis by burning fossil fuels (Jenssen and Kongshaug 2003) and following fertilizer applications (e.g., denitrification). Denitrification losses from the soil are important since soil $\mathrm{N}$ is lost and resulting $\mathrm{NO}$ and $\mathrm{N}_{2} \mathrm{O}$ are gases contributing to the global climate change dilemma (Vitousek et al. 1997). In denitrification, bacteria use the $\mathrm{N}$ atom in $\mathrm{NO}_{3}{ }^{-}$as a terminal electron acceptor (in the absence of oxygen) in the process of carrying sugars through the respiration-glycolysis process in their cells. Under such conditions nitrate is converted to gaseous $\mathrm{N}\left(\mathrm{NO}, \mathrm{N}_{2} \mathrm{O}\right.$, or $\left.\mathrm{N}_{2}\right)$. Continual use of synthetic fertilizers may also reduce soil quality through salt accumulation (Follett et al. 1981; Finck 1982).
Organic fertilizers contain organic matter and include a diverse group of materials that are often classified as either organic farm manures (e.g., animal or green manure) or organic commercial fertilizers (e.g., peat, bone meal, biosolids, compost) (Finck 1982). The majority of the nutrients in organic fertilizers are organically bound and slowly mineralized, so the potential for exceeding plant nutrient demands and associated environmental contamination is reduced relative to synthetic fertilization (Stratton et al. 1995). Because organic fertilizers have lower quantities of immediately available $\mathrm{N}$ compared to synthetic fertilizers, they may be less likely to speed up $\mathrm{CO}_{2}$ release from soil via $\mathrm{N}$-stimulation of microbial respiration (Follett et al. 1981; Triberti et al. 2008). The use of organic materials as fertilizer promotes useful recycling and removes potentially noxious waste products (Finck 1982).

Many studies demonstrate the positive impacts of mulch and compost on soil quality and urban tree health (see reviews by Chalker-Scott 2007; Scharenbroch 2009). However, clients and circumstances often dictate that turfgrass remain under urban trees in lieu of mulch. Furthermore, mulch rings rarely cover the full extent of the rooting area, which recently has been estimated to be 38 times the tree diameter (Day et al. 2010). Compost top-dressing applications on turfgrass show promise for improving soil quality and treating a greater extent of the rooting area (e.g., Watson 1988). However, liquid-based amendments are still a very popular nutrient delivery system for urban trees. Aerated compost teas (ACT) are one such liquid product that is rapidly gaining interest as an arboricultural amendment with the hopes of improving soil quality and managing tree nutrition. A relatively easy transition from synthetic fertilization to ACT may be feasible because much of the existing tech- 
nology (e.g., spraying equipment) for applying fertilizers can be used to apply ACT to urban trees (pers. comm.: R. Bastian of Davey Tree Experts, and J. Lloyd of Rainbow Tree Care).

Aerated compost tea is made by mixing compost with aerated water (NOSB 2004). Aeration during the brewing process distinguishes ACT from other compost extracts, and is important considering the goal of increasing aerobic microorganisms. According to the National Organic Program (NOP), the predominant ACT production method in the United States involves one part compost in 10-50 parts water, constant aeration for 12-24 hours, and immediate application (NOSB 2004). NOP standards specify that compost used to make ACT must be made from allowable feedstock materials and the entire pile must undergo an increase in temperature to at least $55^{\circ} \mathrm{C}$ for at least three days (NOSB 2002). ACT additives-such as molasses, yeast extract, and algal powders-are used to encourage growth of beneficial microbes, but they can also have nontarget negative effects by supporting the growth of bacterial human pathogens from undetectable levels in properly made compost to detectable levels in ACT. The NOSB (2004) specifies that ACT made with additives can be applied to ornamental plants not intended for human consumption, and it is exempt from EPA standards for bacterial indicators of fecal contamination. No standards exist for application rates of ACT in agriculture or horticulture. Current ACT application rates for horticultural and arboricultural plants range from 4 to $400 \mathrm{~kL} \mathrm{ACT} \mathrm{ha-1} \mathrm{(pers.} \mathrm{comm.:} \mathrm{E.} \mathrm{Ing-}$ ham of Soil Foodweb, Inc., and R. Bastian of Davey Tree Experts), albeit these rates are not based on scientific evidence.

Proponents assert that ACT will transfer desirable microorganisms, fine particulate organic matter, and soluble nutrients to soil surfaces. Specifically, unsubstantiated claims are made that ACT will: 1) help retain nutrients via increased microbial immobilization, 2) increase microbial mineralization and make nutrients available at rates plants require them, 3) build soil structure and decrease the effects of compaction, 4) detoxify soil and water, and 5) suppress disease by inducing competition among disease (anaerobic) and beneficial (aerobic) organisms (e.g., Ingham 2003a; Ingham 2003b; Ingham 2004; Lowenfels and Lewis 2007). In comparison to the anecdotal experiences reported by ACT practitioners, relatively few peer-reviewed, controlled, replicated scientific studies have been performed on the impacts of ACT on plants, soil, and the environment (Duffy et al. 2004; Scheurell and Mahaffee 2004; Scheurell and Mahaffee 2006; Larkin 2008; Segarra et al. 2009). Furthermore, consistent findings among these studies have not been reported for the impacts of ACT on plants, soil, or the environment (see review by Scheurell and Mahaffee 2002). The objective of this research was to evaluate ACT, synthetic fertilization, and deionized water control treatments in conjunction with two soil types, for their effects on 15 soil biochemical properties, including denitrification.

\section{MATERIALS AND METHODS}

\section{Making and Monitoring ACT}

Aerated compost tea was made with a KIS compost tea brewer, 18.9 L (Keep It Simple, Inc., Redmond, Washington, U.S.). Deionized water $(18.9 \mathrm{~L})$ was combined with one commercially available package of compost (approximately $500 \mathrm{~g}$ ) containing wood chips, sawdust, rock, minerals, fungal ingredients, humus, and vermicompost (KIS 5 gal compost tea brewing kit from Keep It Simple, Inc., Redmond, Washington). The compost contained 11,648 $\mu \mathrm{g}$ bacteria $\mathrm{g}^{-1}, 3,547 \mu \mathrm{g}$ fungi $\mathrm{g}^{-1}$ (mean hyphae diameter of $\left.2.8 \mu \mathrm{m}\right), 18,883$ flagellates $\mathrm{g}^{-1}$, 14,596 amoebae $\mathrm{g}^{-1}, 11,338$ ciliates $\mathrm{g}^{-1}$, and 1.2 nematodes $\mathrm{g}^{-1}$ (analyses performed by Soil Foodweb, Inc., Corvallis, Oregon, U.S.). A package $(500 \mathrm{~g})$ of microbial food consisting of $80 \%$ organic nutrients, $20 \%$ natural minerals derived from feather meal, bone meal, cottonseed meal, sulfate of potash-magnesia, alfalfa meal, kelp, soymeal, and mycorrhizae was added at the start of brew. Humic acid $(25 \mathrm{~g})$ and soluble seaweed powder $(25 \mathrm{~g})$ were also added at the start of the brew. During the 24-hour brew cycle, dissolved oxygen, temperature, $\mathrm{pH}$, and electrical conductivity were measured every hour. Dissolved oxygen remained above $6 \mathrm{mg} \mathrm{kg}^{-1}$, with a mean value of $7.3 \mathrm{mg} \mathrm{kg}^{-1}$ throughout the brew cycle. Mean temperature, $\mathrm{pH}$, and electrical conductivity were $21^{\circ} \mathrm{C}, 4.9$, and $2,169 \mu \mathrm{S} \mathrm{cm}{ }^{-1}$, respectively. On average (12 brews over 2008 and 2010 under similar conditions described), the ACT contained only a fraction of what was in the compost itself: $1,972 \mu \mathrm{g}$ bacteria $\mathrm{g}^{-1}, 4.9 \mu \mathrm{g}$ fungi $\mathrm{g}^{-1}$ (mean hyphae diameter of $2.6 \mu \mathrm{m}$ ), 1,920 flagellates $\mathrm{g}^{-1}, 1,392$ amoebae $\mathrm{g}^{-1}, 7.7$ ciliates $\mathrm{g}^{-1}$, and 0.1 nematodes $\mathrm{g}^{-1}$. Six replicates of the ACT, fertilizer, water treatments, and baseline soils were analyzed for $\mathrm{pH}, \mathrm{Ca}^{2+}$, $\mathrm{Mg}^{2+}, \mathrm{K}^{+}, \mathrm{Na}^{+}$, total $\mathrm{C}, \mathrm{N}, \mathrm{NH}_{4}^{+}, \mathrm{NO}_{3}^{-}$, dissolved organic $\mathrm{N}$ (DON), microbial biomass $\mathrm{N}(\mathrm{MBN})$, potential $\mathrm{N}$ mineralization $(\mathrm{PMN})$, and microbial respiration (RES) (Table 1). The procedures used for these measurements are described below.

\section{Laboratory Assay I}

Laboratory assay I was a full-factorial experiment with two soil types, four treatments, and six replicates. The four treatments were: deionized water, NPK fertilizer at $195 \mathrm{~kg} \mathrm{~N}^{-1}$, dilute $\mathrm{ACT}\left(\mathrm{ACT}_{\mathrm{d}}\right)$ at $22.4 \mathrm{~kL} \mathrm{ACT} \mathrm{ha}^{-1}$, and concentrate ACT (ACT) at $224 \mathrm{~kL} \mathrm{ACT} \mathrm{ha}^{-1}$. The fertilizer contained $30 \%$ elemental $\mathrm{N}$ (20\% water insoluble synthesized $\mathrm{N}$ and $10 \%$ water-soluble synthesized $\mathrm{N}$ ), $4.4 \%$ elemental $\mathrm{P}$ or $10 \%$ available phosphoric acid $\left(\mathrm{P}_{2} \mathrm{O}_{5}\right)$, and $5.8 \%$ elemental $\mathrm{K}$ or $7 \%$ soluble potash $\left(\mathrm{K}_{2} \mathrm{O}\right)$. The fertilizer $\mathrm{N}$ source is ureaformaldehyde, $\mathrm{P}$ source is monopotassium phosphate, and $\mathrm{K}$ source is monopotassium phosphate. Throughout this paper, the term "fertilizer" is used to represent the synthetic fertilizer, and "ACT" to represent compost tea.

The two soils tested were an A horizon silt loam ( 0 to 10 $\mathrm{cm})$ and Bt horizon clay loam (10 to $25 \mathrm{~cm}$ ) — both from a fine, illitic, mesic Oxyaquic Hapludalf, Ozaukee series soil profile (Kelsey 2000). The two soil types were collected from a two meter wide by three meter deep pit on the grounds of the Morton Arboretum (Lisle, Illinois). Soil was air-dried in the laboratory, passed through a two-millimeter sieve, and thoroughly homogenized. One hundred-gram soil samples were placed into $250 \mathrm{~mL}$ beakers, and liquid treatments were added to bring soils to $60 \%$ water-filled pore space. The treated soils were incubated in the dark at $25^{\circ} \mathrm{C}$ and sampled after 10 days.

After the incubation period, soil sub-samples were extracted with $1 \mathrm{M} \mathrm{NH}_{4} \mathrm{OAc}$ (pH 7.0) and $\mathrm{mg} \mathrm{kg}^{-1}$ of $\mathrm{Ca}^{2+}, \mathrm{Mg}^{2+}, \mathrm{K}^{+}$, and $\mathrm{Na}^{+}$were determined with atomic adsorption spectroscopy (Model A5000, Perkin Elmer, Inc., Waltham, Massachusetts, U.S.) (Schollenberger and Simon 1945). Soil phosphorus was deter- 


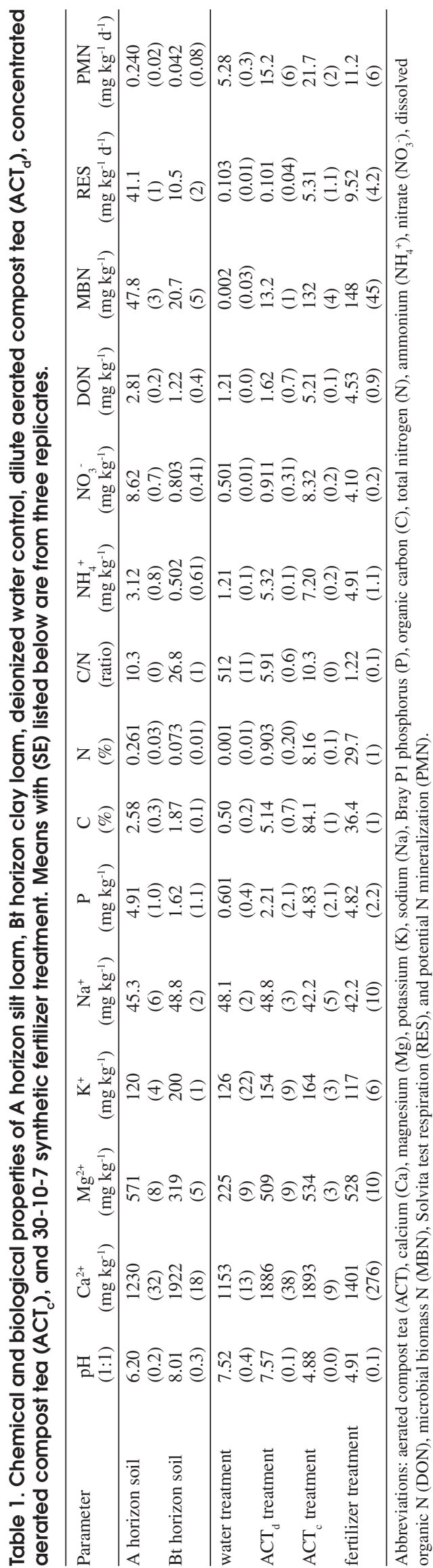

mined with the Bray P-1 extraction and analyzed colorimetrically at $882 \mathrm{~nm}$ on a spectrophotometer (Model UV mini 1240, Shidmadzu, Inc., Kyoto, Japan) (Olsen and Sommers 1982). Soil $\mathrm{pH}$ and electrical conductivity in $\mu \mathrm{cm}^{-1}$ were measured in 1:1 (soil:deionized) water pastes (Model Orion 5-Star, Thermo Fisher Scientific, Inc., Waltham, Massachusetts, U.S.). Total soil C and $\mathrm{N}$ were determined by automated dry combustion on a $\mathrm{CN}$ analyzer (Vario ELIII, Elementar Analysensysteme, Hanau, Germany) (Nelson and Sommers 1996). The soil fumigation-extraction method (Brookes et al. 1985) was used to determine microbial biomass $\mathrm{N}(\mathrm{MBN})$ in $\mathrm{mg} \mathrm{kg}^{-1}$. Soil sub-samples were fumigated with ethanol-free chloroform for five days, extracted with $0.5 \mathrm{M}$ $\mathrm{K}_{2} \mathrm{SO}_{4}$, and total extractable $\mathrm{N}$ was reduced to $\mathrm{NH}_{4}^{+}$with persulfate and Devarda's alloy for $\mathrm{NH}_{4}^{+}$absorbance readings at $650 \mathrm{~nm}$ (Model ELx 800, Biotek Instruments, Inc., Winooski, Vermont, U.S.) (Sims et al. 1995). Microbial biomass $\mathrm{N}$ was the difference in $\mathrm{N}$ between the fumigated and unfumigated samples, using an extraction efficiency factor of $\mathrm{EN}=0.54$ (Joergensen and Mueller 1996). Potential $\mathrm{N}$ mineralization was measured as the net increase or decrease in available $\mathrm{NH}_{4}^{+}$and $\mathrm{NO}_{3}{ }_{3}^{-}$over the 10 day incubation. Nitrate in the $0.5 \mathrm{M} \mathrm{K}_{2} \mathrm{SO}_{4}$ extract was reduced to $\mathrm{NH}_{4}^{+}$using a Devarda's alloy and $0.1 \mathrm{M} \mathrm{H}_{2} \mathrm{SO}_{4}$ and then read colorimetrically, as described (Sims et al. 1995). Carbon dioxide evolution was measured over a 24-hour period using Solvita $\mathrm{CO}_{2}$ respiration paddles and a digital color reader (Haney et al. 2008).

\section{Laboratory Assay II}

The second laboratory assay was a full-factorial experiment with the same two soil types, three treatments, and six replicates. The three treatments were: water, NPK fertilizer (30:10:7) at $195 \mathrm{~kg} \mathrm{~N} \mathrm{ha}^{-1}$ and $\mathrm{ACT}_{\mathrm{c}}$ at $224 \mathrm{~kL} \mathrm{ACT} \mathrm{ha}^{-1}$. Prior to adding the treatments the field-collected soils were dried and passed through a two-millimeter sieve. Sixty grams of each soil were weighed into $100 \mathrm{~mL}$ volumetric flasks. Liquid treatments $(60$ $\mathrm{mL}$ ) were added to the soils bringing them to $100 \%$ water-filled pore space. The headspace of each volumetric flask was purged with helium and immediately capped with rubber septa to allow for gas headspace sampling. Sufficient acetylene was then added to bring the headspace to a 10/90 acetylene/helium mix. The soils were incubated in the dark at $25^{\circ} \mathrm{C}$ for a total of eight days.

Gas sampling for denitrification followed the acetylene inhibition method (Yoshinari and Knowles 1976; Drury et al. 2008). Gas samples were collected from each flask at 12, 24, 48, 96, and 192 hours. Prior to sample injection, $9 \mathrm{~mL}$ of $10 \%$ acetylene and $90 \%$ helium were added to $10 \mathrm{~mL}$ vacuum vials. A $1000 \mu \mathrm{L}$ sample was collected from the flask and added to the vacuum vial. A $1000 \mu \mathrm{L}$ mixture of $10 \%$ acetylene and $90 \%$ helium was added to the flasks to replace the gas removed. A $500 \mu \mathrm{L}$ subsample was extracted from the vacuum vials and concentrations of $\mathrm{N}_{2} \mathrm{O}$ and $\mathrm{CO}_{2}$ were determined using a thermal conductivity gas chromatograph (Hewlett Packard 5710A with Alltech Porapak Q 50/80 in series with Alltech Haysep Q 80/100 column, Agilent Technologies, Foster City, California, U.S.). The carrier gas used was helium, flow rate was $15 \mathrm{~cm}^{3}$ $\mathrm{min}^{-1}$, and detector temperature $100^{\circ} \mathrm{C}$. Peak retention times for $\mathrm{CO}_{2}$ and $\mathrm{N}_{2} \mathrm{O}$ were 8 to 9 minutes and 11 to 12 minutes. Standards $3 \%$ $\mathrm{CO}_{2}$ (Scotty II Analyzed Gas, $\mathrm{CO}_{2}, 3 \%$, PN 24035, Plumsteadville, Pennsylvania, U.S.) and $100 \mathrm{mg} \mathrm{N}_{2} \mathrm{O} \mathrm{kg}^{-1}$ (Matheson Tri-Gas Analyzed Gas, Micro MAT10, $100 \mathrm{mg} \mathrm{kg}^{-1} \mathrm{~N}_{2}$. Item \# GMT10346TK, Oak Creek, Wisconsin, U.S.) were tested daily with samples. 


\section{Statistical Analyses}

Statistical analyses were conducted using SAS JMP 7.0 software (SAS, Inc., Cary, North Carolina, U.S.). Data distributions were checked for normality using the Shapiro-Wilk W test. Transformations of non-normal data were performed with $\log 10$, natural $\log$, square root, or exponential functions. The treatment effects were analyzed using Analysis of Variance (ANOVA). A sequential Bonferroni inequality was applied to the critical $\mathrm{p}$ values to control for false positives (Type I error) associated with multiple testing (Rice 1989). Mean separations were carried out with Tukey-Kramer HSD tests.

\section{RESULTS AND DISCUSSION}

\section{Soil Type Effects}

Significant effects were detected for soil type on all soil properties (Table 2). The A horizon soils had lower $\mathrm{pH}, \mathrm{Ca}^{2+}, \mathrm{K}^{+}$, and $\mathrm{Na}^{+}$, and higher $\mathrm{Mg}^{2+}, \mathrm{P}$, total $\mathrm{C}$, total $\mathrm{N}, \mathrm{NH}_{4}^{+}, \mathrm{NO}_{3}^{-}, \mathrm{DON}, \mathrm{MBN}$, PMN, and RES compared to soils from the Bt horizon. Treatment by soil type interactions were detected for $\mathrm{NH}_{4}^{+}$(Table 2).

\section{Soil $\mathrm{pH}, \mathrm{Ca}, \mathrm{Mg}, \mathrm{K}, \mathrm{Na}$, and $\mathrm{P}$}

Soil $\mathrm{pH}$ was not significantly different in any treatments in either soil type (Table 2). Ammonium addition to soil results in acidification because two $\mathrm{H}^{+}$are generated with the oxidation of each $\mathrm{NH}_{4}^{+}$ion in the process of nitrification (Follet et al. 1981). Evolved $\mathrm{CO}_{2}$ from microorganisms reacts with water to form bicarbonate, and in the process releases $\mathrm{H}^{+}$to solution, also acidifying soil. Relative to water, neither fertilization nor ACT appeared to acidify these soils to produce measureable changes in soil $\mathrm{pH}$. Nonresponses in $\mathrm{pH}$ were likely due to high buffering capacities of these silt and clay loam soils (Kelsey 2000).

With the Bt horizon soils, $\mathrm{Ca}^{2+}$ was significantly greater with water and $\mathrm{ACT}$ treatment compared to the fertilizer treatment (Table 2). Soil $\mathrm{Ca}^{2+}$ did not differ among treatments for the A horizon soils. No differences were observed for soil $\mathrm{Mg}^{2+}$ among the treatments for either soil type. Researchers in this study surmise that the $\mathrm{Ca}^{2+}$ decrease with fertilizer and $\mathrm{ACT}$ is a result of microbial $\mathrm{Ca}^{2+}$ immobilization, since nitrifying bacteria are known to have a high requirement for calcium (Follet et al. 1981). Calcium is primarily applied to soils to change conditions related to its reaction, while $\mathrm{Mg}^{2+}$ is applied to correct a plant nutrient deficiency. Finck (1982) suggests urban soils are rarely deficient in either $\mathrm{Ca}^{2+}$ or $\mathrm{Mg}^{2+}$. Deficiencies of $\mathrm{Ca}^{2+}$ and $\mathrm{Mg}^{2+}$ for crops are expected to occur at approximately 500 and $50 \mathrm{mg} \mathrm{kg}^{-1}$, respectively, which were well below this study's measured values (Walsh and Beaton 1973). It is believed that these soils were not deficient in either of these nutrients. Similar to these results, Hargreaves et al. (2008) found no differences in soil $\mathrm{Ca}^{2+}$ and $\mathrm{Mg}^{2+}$ contents one and two-years after applying fertilizer and non-aerated compost teas made from municipal waste and ruminant compost.

In the A horizon soil, $\mathrm{K}^{+}$was greater with the $\mathrm{ACT}_{c}$ compared to other treatments (Table 2). Soil $\mathrm{K}^{+}$levels in the A horizon soils were greater with fertilizer compared to $\mathrm{ACT}_{\mathrm{d}}$ and water (Table 2). No differences for $\mathrm{K}^{+}$were observed with the Bt horizon soils, which had significantly higher $\mathrm{K}^{+}$concentrations (197 to $205 \mathrm{mg} \mathrm{kg}^{-1}$ ) as compared to the A hori- zon soils (118 to $134 \mathrm{mg} \mathrm{kg}^{-1}$ ). Plants growing in soils with greater than $170 \mathrm{mg} \mathrm{kg}^{-1} \mathrm{~K}^{+}$have been found to be nonresponsive to $\mathrm{K}^{+}$fertilization (Walsh and Beaton 1973). Hargreaves et al. (2008) found soil $\mathrm{K}^{+}$levels to be lower with non-aerated compost teas as compared to inorganic fertilizer, but this was likely due to the compost teas being applied as foliar sprays and fertilization as a soil application. The amounts of $\mathrm{K}^{+}$in $\mathrm{ACT}_{\mathrm{c}}\left(164 \mathrm{mg} \mathrm{kg}^{-1}\right)$ exceeded that in the $30-10-7$ fertilizer (117 $\mathrm{mg} \mathrm{kg}{ }^{-1}$ ) (Table 1). Several studies report increases in soil $\mathrm{K}^{+}$ from compost (Giusquiani et al. 1988; Bar-Tal et al. 2004). This study's findings indicate that $\mathrm{ACT}_{c}$ may also be an effective method of increasing the soil available supply of $\mathrm{K}^{+}$.

Sodium concentrations were not impacted by any of these treatments (Table 2). High $\mathrm{Na}^{+}$levels (exchangeable $\mathrm{Na}^{+} \%>10$, which is $\mathrm{Na}^{+}$divided by the sum of other cations) are detrimental to soil tilth and plant growth (Marx et al. 1996). In this study, the exchangeable $\mathrm{Na}^{+} \%$ values were all $<2 \%$, and so the amendments added to these soils do not appear to present potential soil quality or tree health problems.

Soil $\mathrm{P}$ with the A horizon soil was greater with fertilization compared to other treatments (Table 2). No differences were observed among the treatments for soil $\mathrm{P}$ with the Bt horizon soils, possibly a result of Ca-P precipitation at these higher $\mathrm{pH}$ values (Essington 2003). Annual P use for five southwestern Wisconsin tree species of varying leaf longevities ranged from 6 to 13 $\mathrm{kg} \mathrm{P} \mathrm{ha}^{-1}$ (Son and Gower 1991). Values of less than $5 \mathrm{mg} \mathrm{kg}^{-1}$ for the Bray P test suggest very low corn yields in Minnesota (Rehm et al. 2006). Only the fertilizer treatment increased levels of soil $\mathrm{P}$ to the range of $\mathrm{P}$ usage reported by Son and Gower (1991) and above the $>5 \mathrm{mg} \mathrm{kg}^{-1} \mathrm{P}$ requirement for corn $(6.1$ mg kg-1 $\mathrm{P}$ equating to $15 \mathrm{~kg} \mathrm{P} \mathrm{ha}^{-1}$, assuming $1.0 \mathrm{Mg} \mathrm{m}^{-3}$ and $0.25 \mathrm{~m}$ depth) (Table 2). Similar amounts of $\mathrm{P}$ were contained in the fertilizer and $\mathrm{ACT}_{c}$ treatment (Table 1). Researchers in this study suspect greater microbial P immobilization with ACT compared to fertilizer. Phosphorus immobilization is great with organic materials low in $\mathrm{P}$ content relative to energy sources (i.e., C contents) (Sauchelli 1965). The C/P ratio of the ACT was 18/1 compared to the $8 / 1$ for the fertilizer treatment. Assuming soil $\mathrm{pH}$ is not limiting $\mathrm{P}$ availability, fertilization appears to be more effective than ACT at increasing P levels in A horizon soils.

\section{Soil $\mathrm{C}$ and $\mathrm{N}$}

No differences were observed in total $\mathrm{C}$ or $\mathrm{N}$ in either soil type with these treatments (Table 2). Total $\mathrm{C}$ and $\mathrm{N}$ are relatively stable pools, so researchers in this study did not expect these one-time treatments to have significant effects after only 10 days. Soil $\mathrm{C}$ has been thought to increase with fertilization by increasing the input of plant residues. However, recent results from the Morrow Plots, the world's oldest experimental site under continuous corn (Zea mays L.), indicate that after 40 to 50 years of synthetic fertilization that exceeded grain $\mathrm{N}$ removal by $60 \%$ to $190 \%$, a net decline occurred in soil C despite increasingly massive residue $\mathrm{C}$ incorporation (Khan et al. 2007; Mulvaney et al. 2009). The decline in soil C with long-term fertilization was attributed to the excess fertilizer $\mathrm{N}$ promoting the decomposition of residues and soil $\mathrm{C}$. To date, no studies have investigated the long-term impacts on soil $\mathrm{C}$ and $\mathrm{N}$ storage of fertilization or ACT application to urban trees.

Soil $\mathrm{NO}_{3}^{-}$(Bt horizon only) and DON were greater with the fertilizer compared to the ACT treatments and water controls 


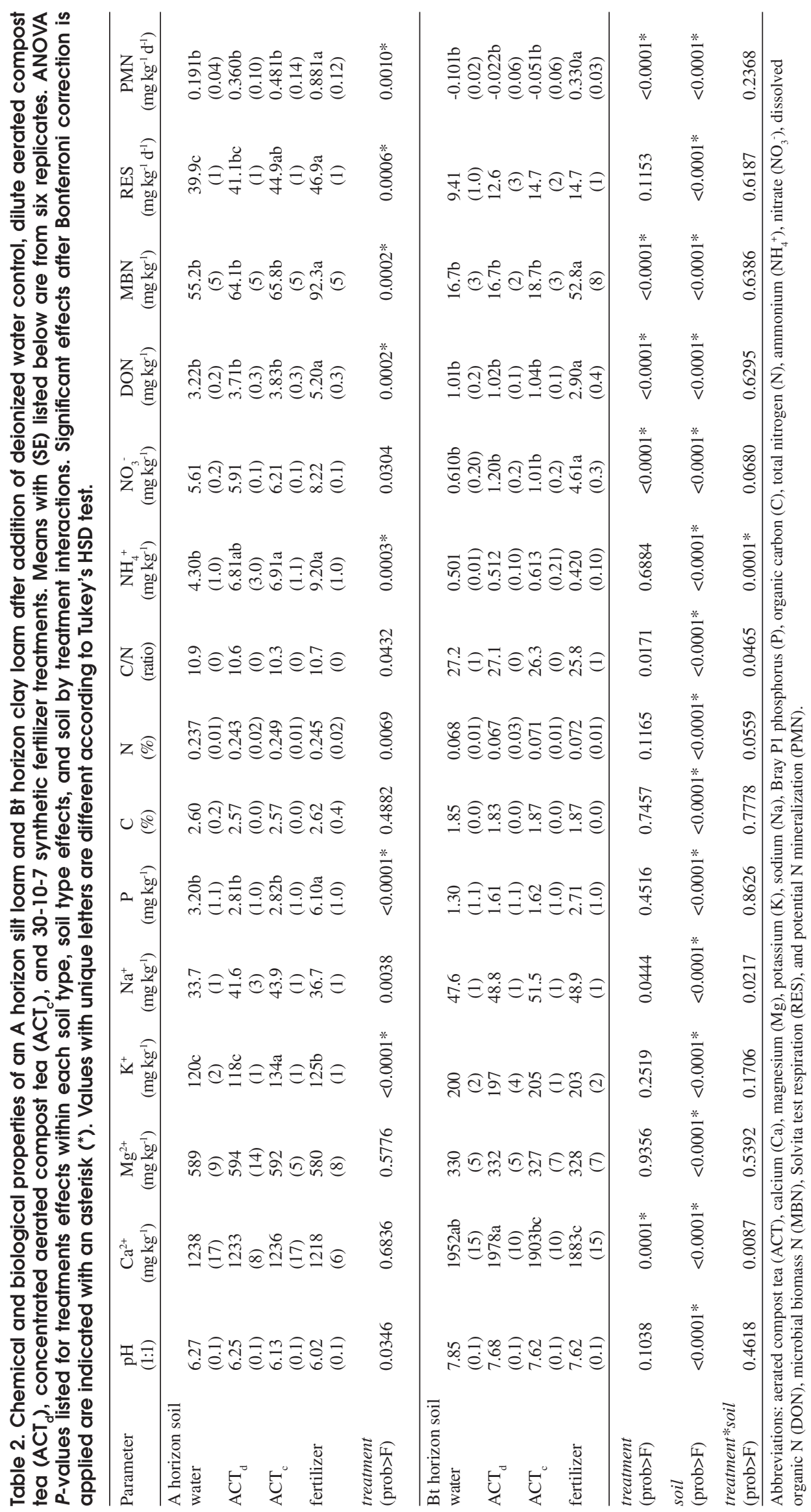


(Table 2). Soil $\mathrm{NH}_{4}^{+}$was greater with $\mathrm{ACT}$ and fertilizer compared to water in the A horizon soil (Table 2). No differences were observed for these $\mathrm{N}$ pools between the $\mathrm{ACT}_{\mathrm{d}}$ treatments and water, in either soil type. In a typical soil $\left(1.0 \mathrm{Mg} \mathrm{m}^{-3}\right.$ and top $25 \mathrm{~cm}$ ), $50 \mathrm{mg} \mathrm{kg}^{-1} \mathrm{~N}$ would equate to $127 \mathrm{~kg} \mathrm{~N} \mathrm{ha}^{-1}$, and would fall within the current ANSI standard fertilization application rate of 98 to $195 \mathrm{~kg} \mathrm{~N} \mathrm{ha}^{-1}$ (ANSI 2004). Combining the plant available $\mathrm{N}$ pools of $\mathrm{NH}_{4}^{+}, \mathrm{NO}_{3}^{-}, \mathrm{DON}$, and $\mathrm{MBN}$, the results of this study indicate that none of the A horizon soils would be deficient in $\mathrm{N}\left(68.3,80.5,82.7\right.$, and $114.9 \mathrm{mg} \mathrm{kg}^{-1}$ for water, $\mathrm{ACT}_{\mathrm{d}}$, $\mathrm{ACT}_{c}$, and fertilizer, respectively). Nitrogen deficiencies may exist with the Bt soils for the water $\left(18.4 \mathrm{mg} \mathrm{kg}^{-1}\right), \mathrm{ACT}_{\mathrm{d}}(19.4 \mathrm{mg}$ $\left.\mathrm{kg}^{-1}\right)$, and ACT $\left(21.3 \mathrm{mg} \mathrm{kg}^{-1}\right)$, but not for the fertilizer treatment $\left(60.7 \mathrm{mg} \mathrm{kg}^{-1}\right)$. The findings of this study demonstrate that fertilizer is best at increasing $\mathrm{NO}_{3}{ }^{-}$and $\mathrm{DON}$ levels in the soil, but $\mathrm{ACT}_{c}$ and fertilizer both increased soil $\mathrm{NH}_{4}{ }^{+}$in A horizon soils.

\section{Soil Microbial Biomass, Respiration, N Mineral- ization, and Denitrification}

In the A horizon soils, MBN was 67,44 , and $39 \%$ greater with fertilizer compared to water, $\mathrm{ACT}_{\mathrm{d}}$, and $\mathrm{ACT}_{\mathrm{c}}$, respectively (Ta- ble 2). Microbial biomass $\mathrm{N}$ in the Bt horizon with fertilizer was $216 \%, 216 \%$, and $182 \%$ greater compared to water, $\mathrm{ACT}_{d}$, and $\mathrm{ACT}_{c}$, respectively (Table 2 ). Microbial biomass $\mathrm{N}$ was not increased with either ACT treatment compared to water (Table 2). The researchers conclude that a one-time fertilizer application increased the existing soil microbial biomass $\mathrm{N}$ pool in excess of the microbial biomass $\mathrm{N}$ added in a one-time ACT treatment.

The Solvita test $\mathrm{CO}_{2}$ respiration (RES) values for ACT and fertilizer were greater than water for the A horizon soils (Table 2). No differences were observed for RES among the treatments for the $\mathrm{Bt}$ horizon soils. Fertilizer $\mathrm{CO}_{2}$ efflux exceeded water at all times and both soil types (sans hour 196 for the Bt horizon) (Figure 1). $\mathrm{CO}_{2}$ efflux was greater with fertilizer compared to $\mathrm{ACT}_{\mathrm{c}}$ at hours 12 and 196 for the A horizon soil, and at hours $12^{\mathrm{c}}, 24,48$, and 96 for the Bt horizon soils (Figure 1). With the A horizon soils, $\mathrm{CO}_{2}$ efflux with $\mathrm{ACT}_{\mathrm{c}}$ was greater than water at hours 12 and 24 (Figure 1). At hours 12, 24, 48, and 96 ACT $\mathrm{CO}_{2}$ efflux exceeded water for the Bt horizon soils (Figure 1). The data show that ACT, compared to water, temporarily increases microbial respiration. Larkin (2008) showed significantly greater microbial substrate utilization in Biolog plates with ACT compared to
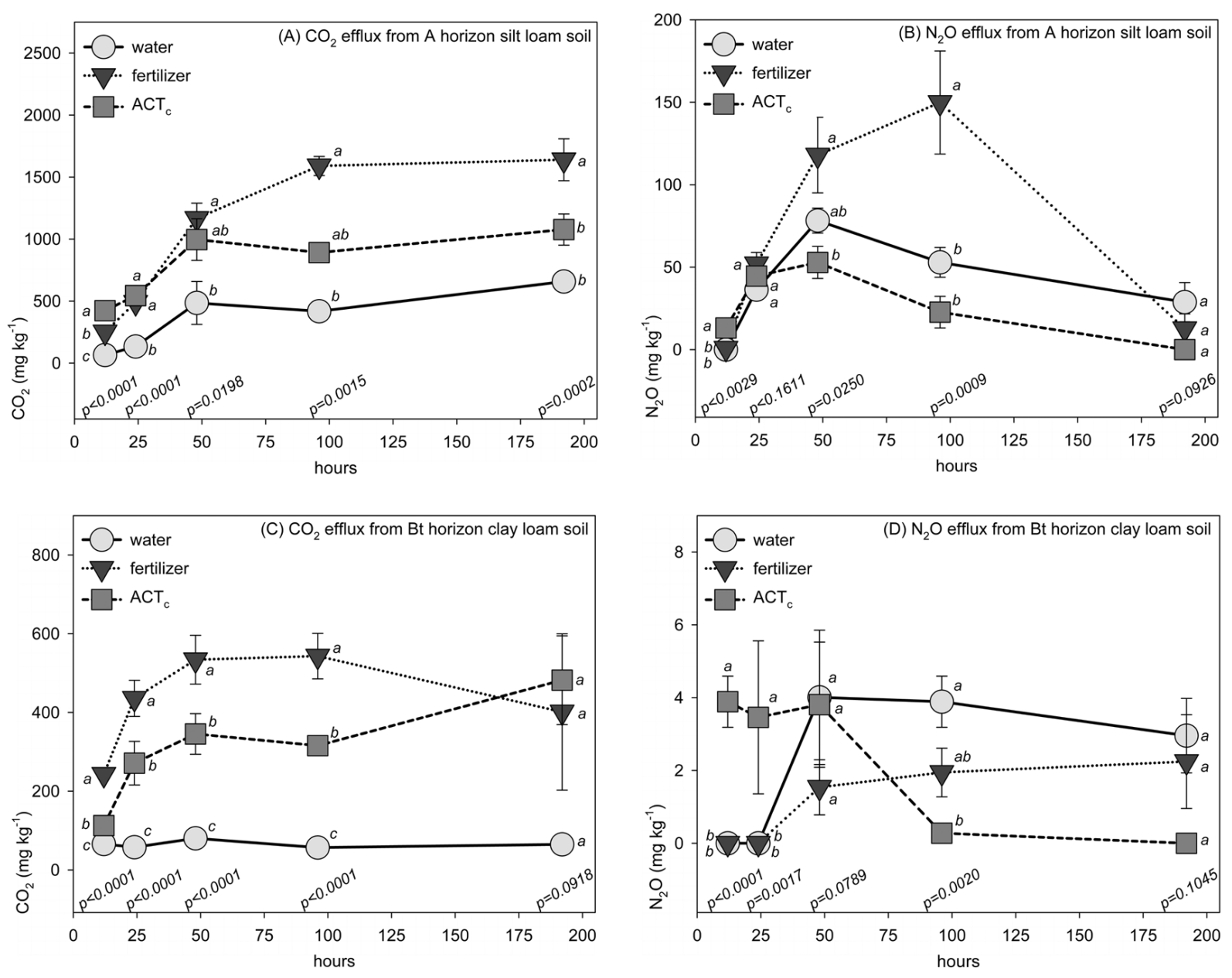

Figure 1. $\mathrm{CO}_{2}$ and $\mathrm{N}_{2} \mathrm{O}$ efflux from $\mathrm{A}$ and $\mathrm{Bt}$ horizon soils treated with concentrated aerobic compost tea (ACT), fertilizer, or deionized water under saturated conditions over a 192-hour laboratory assay. Each point is a mean of six replicates, with error bars showing standard error of the mean. $P$-values are given for each ANOVA at each collection time. Unique letters identify differences with Tukey's HSD test. Means, standard errors, and Tukey's HSD differences are also listed for samples averaged over the entire 192-hour assay. 
control soils. However, the study authors conclude that microbial respiration is, for the most part, greatest with fertilizer.

Nitrogen mineralization was greater with fertilization compared to water and ACT treatments in both soil types (Table 2). Rates of $\mathrm{N}$ mineralization for the A horizon soils extended over a 180-day growing season would be: 86 (water), $162\left(\mathrm{ACT}_{\mathrm{d}}\right.$ ), 216 ( $\mathrm{ACT}_{\mathrm{c}}$ ), and 396 (fertilizer) $\mathrm{kg} \mathrm{N} \mathrm{ha}^{-1}$. Annual $\mathrm{N}$ requirements for five tree species in southwestern Wisconsin were 38 for Pinus resinosa Ait., 80 for Pinus strobus L., 81 for Picea abies (L) Karst, 86 for Larix decidua Miller, and $126 \mathrm{~kg} \mathrm{~N}^{-1}$ for Quercus rubra L. (Son and Gower 1991). Soil N in the fertilization treatment exceeded these reported tree $\mathrm{N}$ requirements by as much as ten-fold. Soil $\mathrm{N}$ in the ACT treatments exceeded tree $\mathrm{N}$ requirements by up to five-fold. Soil $\mathrm{N}$ with the water treatment appeared to best match estimated tree $\mathrm{N}$ requirements. In the Bt horizon soils, only the fertilizer treatment increased $\mathrm{N}$ mineralization (149 $\mathrm{kg} \mathrm{N} \mathrm{ha}^{-1}$ ) to a range close to meeting the tree $\mathrm{N}$ demands (Table 2). Nitrogen immobilization (i.e., negative potential $\mathrm{N}$ mineralization) was measured in the Bt horizon soils for the water and ACT treatments. Increased soil $\mathrm{N}$ mineralization is important for tree nutrition in urban soils, but $\mathrm{N}$ immobilization in the microbial biomass may also be important for nutrient retention in disturbed urban landscapes with a high propensity for nutrient losses to the hydrosphere or atmosphere.

In the A horizon soils, it was found that $\mathrm{N}_{2} \mathrm{O}$ efflux increased with fertilizer compared to $\mathrm{ACT}_{c}$ at hours $48(+65 \mathrm{mg}$ $\left.\mathrm{kg}^{-1}\right)$ and $96\left(+127 \mathrm{mg} \mathrm{kg}^{-1}\right)$ of the 192-hour laboratory assay (Figure 1). At hour 12 in the A horizon soil, $\mathrm{N}_{2} \mathrm{O}$ efflux was greater with $\mathrm{ACT}$ compared to fertilizer and water, but the $+12 \mathrm{mg} \mathrm{kg}^{-1}$ increase was five to 11 times less than the fertilizer-associated $\mathrm{N}_{2} \mathrm{O}$ increase at hours 48 and 96 (Figure 1). At hours 12 and 24 with the Bt horizon soils, $\mathrm{N}_{2} \mathrm{O}$ efflux was approximately $+4 \mathrm{mg} \mathrm{kg}^{-1}$ greater with ACT than water or fertilizer. No differences were observed at hours 24 and 196 for the A horizon and at hours 48 and 192 for the Bt horizon soils.

Environmental influences on denitrification include denitrifying organisms, $\mathrm{pH}$, temperature, oxygen, moisture, oxidizable organic matter, and the amount of $\mathrm{NO}_{3}^{-}$present (Follet et al. 1981). The researchers in this study suspect increases in readily available $\mathrm{NO}_{3}^{-}$with the fertilizer treatment explain the larger increases in $\mathrm{N}_{2} \mathrm{O}$ efflux with fertilization in the A-horizon soils at hours 24 and 48 . The authors believe the initial denitrification increases with $\mathrm{ACT}$ were a consequence of increased available dissolved organic ${ }^{\mathrm{C}}$ in the ACT (Table 1). The researchers are aware of no other studies comparing denitrification responses of ACT and fertilization. Alluvione et al. (2010) found that compost application reduced the $\mathrm{CO}_{2}$ equivalent of combined $\mathrm{N}_{2} \mathrm{O}$ and $\mathrm{CO}_{2}$ efflux by $49 \%$ compared to urea fertilization, and proposed that the availability of $\mathrm{N}$ to soil organisms was the likely driving factor in greater spring $\mathrm{N}_{2} \mathrm{O}$ emissions following fertilization. Although the study authors observed increases in denitrification with $\mathrm{ACT}_{c},\left(+4\right.$ to $\left.+12 \mathrm{mg} \mathrm{N}_{2} \mathrm{O} \mathrm{kg}^{-1}\right)$, the greatest absolute increases were observed with the fertilizer treatment in the A horizon soils ( +65 to $\left.+127 \mathrm{mg} \mathrm{N}_{2} \mathrm{O} \mathrm{kg}{ }^{-1}\right)$.

\section{CONCLUSION}

Over these short-term laboratory assays, ACT appears inferior compared to fertilizer in its ability to increase microbial biomass, microbial activity, $\mathrm{DON}, \mathrm{NO}_{3}^{-}$, and $\mathrm{P}$ in soil. These results show $\mathrm{ACT}_{\mathrm{c}}$ to increase soil $\mathrm{K}^{+}, \mathrm{NH}_{4}^{+}$, and microbial respiration compared to water. In A horizon soils, $\mathrm{NH}_{4}^{+}$levels with $\mathrm{ACT}_{c}$ equaled fertilizer, and $\mathrm{K}^{+}$levels with $\mathrm{ACT}_{\mathrm{c}}$ were greater when compared to fertilizer. In the A horizon soils, the greatest potential of surplus available $\mathrm{N}$ was observed with the fertilizer treatment. Only the fertilizer treatment appeared to deliver enough available $\mathrm{N}$ to potentially meet tree needs in the Bt horizon soils. Lower total $\mathrm{N}_{2} \mathrm{O}$ efflux and greater microbial immobilization were observed with ACT compared to fertilizer showing greater potential nutrient retention with ACT compared to fertilizer. Urban soils are often infertile and highly disturbed, so nutrient limitations and potential losses are pertinent considerations for arborists and urban foresters. This research shows that fertilization is more effective at increasing short-term soil nutrient availability, but nutrient retention may be better preserved with ACT or water. The resource and application costs of water, ACT, and fertilizer must be weighed against the potential benefits these treatments may provide. The ACT contained only a fraction of the organisms found in the compost, and future research should examine compost and other organic fertilizer as soil amendments in comparison to ACT, synthetic fertilization, or water.

Acknowledgments. The authors gratefully acknowledge financial support from the TREE Fund Hyland R. Johns Grant (08-HJ-02), and The Morton Arboretum Endowment. We thank the Morton Arboretum Soil Science laboratory volunteers and student interns for their

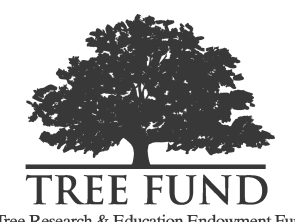
assistance. We thank the reviewers for their insightful critiques and comments provided during the preparation of this manuscript.

\section{LITERATURE CITED}

Alluvione, F., C. Bertora, L. Zavattaro, and C. Grignani. 2010. Nitrous oxide and carbon dioxide emissions following green manure and compost fertilization in corn. Soil Science Society American Journal 74:384-395.

American National Standards Institute (ANSI). 2004. A300 Standard for tree care operations - tree, shrub, and other woody plant maintenance - standard practices (Fertilization, Part 2). American National Standards Institute, New York, New York.

Bar-Tal, A., U. Yermiyahu, J. Beraud, M. Keinan, R. Rosenberg, D. Zohar, V. Rosen, and P. Fine. 2004. Nitrogen, phosphorus, and potassium uptake by wheat and their contributions in soil following successive, annual compost applications. Journal of Environmental Quality 33:1855-1866.

Brookes, P.C., A. Landman, G. Pruden, D.S. Jenkinson. 1985. Chloroform fumigation and the release of soil nitrogen: A rapid direct extraction method to measure microbial biomass nitrogen in soil. Soil Biology and Biochemistry 17:837-842.

Chalker-Scott, L. 2007. Impact of mulches on landscape plants and the environment - A review. Journal Environmental Horticulture 25: 239-249.

Corsi, S.R., D.J. Graczyk, D.W. Owens, and R.T. Bannerman. 1997. Unitarea loads of suspended sediment, suspended solids, and total phosphorus from small watersheds in Wisconsin. U.S. Department of Interior, U.S. Geological Survey, Fact Sheet FS-195-97. Middleton, Wisconsin.

Day, S.D., E.P. Wiseman, S.B. Dickinson, and R.J. Harris. 2010. Contemporary concepts of root system architecture of urban trees. Arboriculture \& Urban Forestry 36:149-159. 
Driscoll, C.T., D. Whitall, J. Aber, E. Boyer, M. Castro, C. Cronan, C.L. Goodale, P. Groffman, C. Hopkinson, K. Lambert, G. Lawrence, and S. Ollinger. 2003. Nitrogen pollution in the Northeastern United States: sources, effects, and management options. BioScience 53:357-374

Drury, C.F., D.D. Myrold, E.G. Beauchamp, and W.D. Reynolds. 2008. Denitrification techniques for soils. pp. 471-481. In: M.R. Carter and E.G. Gregorich (Ed.). Soil Sampling and Methods of Analysis. Candian Society of Soil Science. CRC Press. Boca Raton, Florida.

Duffy, B., C. Sarreal, R. Subbarao, and L. Stanker. 2004. Effect of molasses on regrowth of E. coli O157:H7 and Salmonella in compost teas. Compost Science and Utilization. 12:93-96.

Essington, M.E. 2003. Soil and Water Chemistry: An Integrated Approach. CRC Press, LLC. Boca Raton, Florida.

Finck, A. 1982. Fertilizers and Fertilization. Introduction and Practical Guide to Crop Fertilization. Verlag Chemie, Deerfield Beach, Florida.

Follett, R.H., L.S. Murpy, and R.L. Donahue. 1981. Fertilizers and Soil Amendments. Prentice Hall, Inc., New Jersey.

Giusquiani, P.L., C. Marucchini, and M. Businelli. 1988. Chemical properties of soils amended with compost of urban waste. Plant Soil 109:73-78.

Halvorson, A.D., C.A. Reule, and R.F. Follett. 1999. Nitrogen fertilization effects on soil carbon and nitrogen in a dryland cropping system. Soil Science Society American Journal 63:912-917.

Haney, R.L., W.F. Brinton, and E. Evans. 2008. Soil $\mathrm{CO}_{2}$ respiration: Comparison of chemical titration, $\mathrm{CO}_{2}$ IRGA analysis, and the Solvita gel system. Renewable Agriculture and Food Systems 23:171-176.

Hargreaves, J.C., M. Sina Adl, P.R. Warman. 2008. Are compost teas an effective nutrient amendment in the cultivation of strawberries? Soil and plant tissue effects. Journal Science Food Agriculture 89: 390-397.

Ingham, E. 2003a. Compost Tea Brewing Manual. Soil Foodweb, Inc., Corvallis, Oregon.

Ingham, E. 2003b. Compost tea: Promises and practicalities. Acres 33:1-5.

Ingham, E. 2004. Compost Tea Quality: Light Microscopic Methods. Soil Foodweb, Inc., Corvallis, Oregon.

Jenssen, T.K., and G. Kongshaug. 2003. Energy consumption and greenhouse gas emissions in fertilizer production. Proceedings 509 from International Fertilization Society. York, UK

Joergensen, R.G., and T. Mueller. 1996. The fumigation-extraction method to estimate soil microbial biomass: Calibration of the kEN value. Soil Biology and Biochemistry 28:33-37.

Kelsey, P. 2000. Soils Survey of the Morton Arboretum. Soil taxa description issued by Soil Survey of DuPage and part of Cook counties, Illinois. USDA-NRCS Soil Series Division and Illinois Agriculture Experiment Station.

Khan, S.A., R.L. Mulvaney, and C.W. Boast. 2007. The myth of nitrogen fertilization for soil carbon sequestration. Journal of Environmental Quality 36:1821-1832.

Larkin, R.P. 2008. Relative effects of biological amendments and crop rotations on soil microbial communities and soilborne diseases of potato. Soil Biology and Biochemistry 40:1341-1351.

Lowenfels, J., and W. Lewis. 2007. Teaming with Microbes: A Gardener's Guide to the Soil Food Web. Timber Press, Portland, Oregon.

Marx, E.S., J. Hart, and R.G. Stevens. 1996. Soil test interpretation guide. Oregon State University Extension Service. EC 1478. Corvallis, Oregon.

Mitsch, W.J., J.W. Day Jr., J.W. Gilliam, P.M. Groffman, D.L. Hey, G.W. Randall, and N. Wang. 2001. Reducing nitrogen loading to the Gulf of Mexico from the Mississippi River basin: Strategies to counter a persistent ecological problem. BioScience 51:373-388.

Mulvaney, R.L., S.A. Khan, and T.R. Ellsworth. 2009. Synthetic nitrogen fertilizers deplete soil nitrogen: a global dilemma for sustainable cereal production. Journal of Environmental Quality 38:2295-2314.

National Organic Standards Board (NOSB). 2004. Compost Tea Task Force Report. Accessed 09/04/2010. <http://www.ams.usda.gov/ nosb/archives/crop/recommendations/html>

National Organic Standards Board (NOSB). 2002. Compost Task Force Recommendation. Accessed 09/04/2010. <http://www.ams.usda.gov/ nosb/archives/crop/recommendations/html>

Nelson, D.W., and L.E. Sommers. 1996. Total carbon, organic carbon, and organic matter. pp. 961-1010. In: D.L. Sparks et al. (Eds.). Methods of Soil Analysis Part 2: Soil Science Society of America. Madison, Wisconsin.

Olsen, S.R., and L.E. Sommers. 1982. Phosphorus. pp. 403-430. In: A.L. Page et al. (Eds.). Methods of Soil Analysis Part 2: Soil Science Society of America. Madison, Wisconsin,

Rehm, G., G. Randall, J. Lamb, and R. Eliason. 2006. Fertilizing corn in Minnesota. University of Minnesota Extension. FO-3790-C. St. Paul, Minnesota.

Rice, W.R. 1989. Analyzing tables of statistical tests. Evolution 43: 223-225.

Sauchelli, V. 1965. Phosphates in Agriculture. Reinhold Publishing Corporation. New York.

Scharenbroch, B.C. 2009. A meta-analysis of studies published in Arboriculture \& Urban Forestry relating to organic materials and impacts on soil, tree, and environmental properties. Arboriculture \& Urban Forestry 35:221-231.

Scheuerell S.J., and W.F. Mahaffee. 2004. Compost tea as a container medium drench for suppressing seedling damping off caused by Pythium ultimum. Phytopathology 94:1156-1163.

Scheuerell S.J., and W.F. Mahaffee. 2006. Variability associated with suppression of gray mold (Botrytis cinerea) on geranium by foliar applications of nonaerated and aerated compost teas. Plant Disease 90:1201-1208.

Scheurell, S., and W. Mahaffee. 2002. Compost tea: Principals and prospects for plant disease control. Compost Science and Utilization. 10:313-338

Schollenberger, C.J,. and R.H. Simon. 1945. Determination of exchange capacity and exchangeable bases in soils - ammonium acetate method. Soil Science 59:13-24.

Segarra, G., M. Reis, E. Casanova, and M.I. Trillas. 2009. Contol of powdery mildew (Erysiphe polygoni) in tomato by foliar applications of compost tea. Journal of Plant Pathology 91:683-689.

Sims, G.K., T.R. Ellsworth, and R.L. Mulvaney. 1995. Microscale determination of inorganic nitrogen in water and soil extracts. Communications in Soil Science Plant Analysis 26:303-316.

Soldat, D.J., and A.M. Petrovic. 2008. The fate and transport of phosphorus in the turfgrass ecosystems. Crop Science 48:2051-2065.

Son, Y., and S.T. Gower. 1991. Aboveground nitrogen and phosphorus use by five plantation-grown trees with different leaf longevities. Biogeochemistry 14:167-191.

Stratton, M.L., A.V. Barker, and J.E. Rechcigl. 1995. Compost. pp. 249310. In: J.E. Rechcigl (Ed.). Soil Amendments and Environmental Quality. Lewis Publishers, London.

Triberti, L., A. Nastri, G. Giordani, F. Comellini, G. Baldoni, and G. Toderi. 2008. Can mineral and organic fertilization help sequester carbon dioxide in cropland? European Journal of Agronomy 29:13-20. 
Vitousek, P.M., J.D. Aber, R.W. Howarth, G.E. Likens, P.A. Matson, D.W. Schindler, W.H. Schlesinger, and D.G. Tilman. 1997. Human alteration of the global nitrogen cycle: Sources and consequences. Ecological Applications 7:737-750.

Walsh, L.M., and J.D. Beaton. 1973. Soil Testing and Plant Analysis. Soil Science Society of America, Inc. Madison, Wisconsin.

Watson, G.W. 1988. Organic mulch and grass competition influence tree root development. Journal of Arboriculture 14:200-203.

Yoshinari, T., and R. Knowles. 1976. Acetylene inhibition of nitrous oxide reduction by denitrifying bacteria. Biochemical and Biophysical Research Communications 69:705-710.

Bryant C. Scharenbroch (corresponding author)

Soil Scientist

The Morton Arboretum

4100 Illinois Route 53

Lisle, Illinois 60532-1293, U.S.

BScharenbroch@mortonarb.org

William Treasurer

Volunteer

The Morton Arboretum

4100 Illinois Route 53

Lisle, Illinois 60532-1293, U.S.

Michelle Catania

Research Assistant

The Morton Arboretum

$4100 I l l i n o i s$ Route 53

Lisle, Illinois 60532-1293, U.S.

Vincent Brand

Volunteer

The Morton Arboretum

4100 Illinois Route 53

Lisle, Illinois 60532-1293, U.S.
Résumé. Le thé de compost gagne en intérêt comme amendement nutritif pour les arbres urbains. Cette étude examine les effets du thé de compost, des engrais synthétiques et de l'eau dé-ionisée en regard de 15 propriétés biochimiques de deux types de sols différents. Aucun effet significatif en regard du $\mathrm{pH}$, des quantités en $\mathrm{Mg}^{2+}$, en $\mathrm{Na}^{2+}$, en $\mathrm{C}$ et en $\mathrm{N}$, ainsi que du ratio $\mathrm{C} / \mathrm{N}$ n'a été observé entre les divers traitements. Aucune différence entre le compost de thé dilué à $22,4 \mathrm{~kL} / \mathrm{ha}$ et l'eau n'a été détecté. Le taux en $\mathrm{K}^{+}$du sol était plus grand avec le thé de compost concentré à $224 \mathrm{~kL} / \mathrm{ha}$ comparativement à un engrais 30-10-7 à un taux de $195 \mathrm{~kg}$ en azote à l'hectare. Les quantités en $\mathrm{K}^{+}$, et $\mathrm{NH}_{4}^{+}$, ainsi que la respiration microbienne du sol, étaient plus élevées avec le thé de compost concentré comparativement à l'eau dans les sols A. Dans le sol $\mathrm{P}$ (sol A uniquement), les quantités en $\mathrm{NO}_{3}$ - (sols Bt uniquement), en $\mathrm{N}$ organique dissout, en biomasse microbienne en $\mathrm{N}$ et en $\mathrm{N}$ minéralisé étaient plus grandes avec les engrais comparativement au thé de compost. Une dénitrification accrue était observée avec le thé de compost concentré comparativement à l'engrais et à l'eau dans les premiers 24 heures (+4 à $+12 \mathrm{mg}$ en $\left.\mathrm{N}_{2} \mathrm{O}\right) / \mathrm{kg}$ ), mais un accroissement plus grand était observé avec l'engrais à 48 et 96 heures après $\left(+65\right.$ à $+127 \mathrm{mg}$ en $\left.\mathrm{N}_{2} \mathrm{O}\right)$ / $\mathrm{kg}$ ). Les meilleures améliorations dans la fertilité du sol ont été observées avec l'engrais. Des améliorations mineures dans la fertilité du sol ont été observées avec le thé de compost concentré et les perte en dénitrification ont été plus faibles avec le thé de compost concentré comparativement à l'engrais.

Zusammenfassung. Belüfteter Komposttee (ACT) als Nährstofflieferant wird für Straßenbäume zunehmend interessant. Diese Studie untersucht die Effekte von ACT, synthetischem Dünger und deionisiertem Wasser auf 15 biochemischen Standorten mit zwei verschiedenen Bodentypen. Während der Behandlung wurden keine signifikanten Auswirkungen auf $\mathrm{pH}, \mathrm{Mg}^{2+}, \mathrm{Na}^{+}, \mathrm{C}, \mathrm{N}$, und $\mathrm{C} / \mathrm{N}$-Verhältnis beobachtet. Zwischen verdünntem ACT $\left(\mathrm{ACT}_{\mathrm{d}}\right)$ bei $22.4 \mathrm{kLha}^{-1}$ and Wasser wurde kein Unterschied entdeckt. Der Bodengehalt an $\mathrm{K}^{+}$war größer mit ACT Konzentrat $\left(\mathrm{ACT}_{\mathrm{c}}\right.$ ) bei $224 \mathrm{~kL} \mathrm{ha}^{-1}$ verglichen mit 30-10-7 Dünger bei $195 \mathrm{~kg} \mathrm{~N} \mathrm{ha}^{-1}$ mit A Horizont-Böden.

Der Bodengehalt an $\mathrm{K}^{+}, \mathrm{NH}^{+}$, und die mikrobielle Atmung war größer mit $\mathrm{ACT}$ verglichen mit Wasser in A Böden. Der Bodengehalt an $\mathrm{P}$ (nur bei A Böden) rep. $\mathrm{NO}_{3}$ - (nur Bt Böden),

gelöster organischer Stickstoff, mikrobielle Biomasse und Stickstoffmineralisation war bei gedüngten Böden besser als bei ACT. Zunahmen bei der Denitrifikation wurden bei ACT in Vergleich mit Dünger und Wasser innerhalb der ersten $24 \mathrm{~h}$ beobachtet, aber stärkere Zunahmen wurden beim Dünger bei 48 und $96 \mathrm{~h}\left(+65\right.$ to $\left.+127 \mathrm{mg} \mathrm{N}_{2} \mathrm{O} \mathrm{kg}^{-1}\right)$ gemessen. Die größten Verbesserungen in der Bodenfruchtbarkeit wurden bei der Düngung beobachtet. Kleinere Verbesserungen der Bodenfruchtbarkeit wurden bei ACT beobachtet und die Denitrifikationsverluste waren mit ACT geringer im Vergleich zu Dünger.

Resumen. El compost de té ACT (por sus siglas en inglés) está ganando interés como un nutriente mejorador para árboles urbanos. Este estudio examinó los efectos de ACT, fertilizante sintético y agua de-ionizada sobre 15 propiedades bioquímicas con dos tipos de suelos. No fueron observados efectos significantes entre los tratamientos para $\mathrm{pH}, \mathrm{Mg}^{2+}, \mathrm{Na}^{+}, \mathrm{C}, \mathrm{N}$, y relación $\mathrm{C} / \mathrm{N}$. No se detectaron diferencias entre dilutos ACT $\left(\mathrm{ACT}_{\mathrm{d}}\right.$ ) a $22.4 \mathrm{~kL} \mathrm{ha}^{-1} \mathrm{y}$ agua. $\mathrm{K}+$ del suelo fue mayor con ACT concentrado (ACT ) a $224 \mathrm{~kL} \mathrm{ha}^{-1}$ comparado a fertilizante 30-10-7 a $195 \mathrm{~kg} \mathrm{~N} \mathrm{ha}^{-1}$ con el horizonte A del suelo. $\mathrm{El} \mathrm{K}^{+}, \mathrm{NH}_{4}^{+}$en el suelo y la respiración microbial fueron mayores con ACT comparado con agua en suelos A. El P del suelo (suelos A solamente), $\mathrm{NO}_{3}-$ (Bt suelos solamente), $\mathrm{N}$ orgánico disuelto, biomasa de $\mathrm{N}$ microbial y mineralización de $\mathrm{N}$ fueron mayores con fertilizante comparado con ACT. Los incrementos en denitrificación fueron vistos con ACT, comparados a fertilizante y agua en las primeras 24 horas $\left(+4 \mathrm{a}+12 \mathrm{mg} \mathrm{N}_{2} \mathrm{O} \mathrm{kg}^{-1}\right)$, pero mayores incrementos fueron observados con fertilizante a 48 y 96 horas $(+65 \mathrm{a}+127$ $\mathrm{mg} \mathrm{N}_{2} \mathrm{O} \mathrm{kg}^{-1}$ ). Los mayores mejoramientos en fertilidad del suelo fueron observados con fertilización. Los menores mejoramientos en fertilidad del suelo fueron observados con ACT y las pérdidas de denitrificación fueron más bajas con ACT comparado con el fertilizante. 